\title{
History of dermatology and venereology in Serbia - part IV/1: Dermatovenereology in Serbia from 1919 - 1945
}

\author{
Bosiljka M. LALEVIĆ-VASIĆ ${ }^{1 *}$ and Marina JOVANOVIĆ ${ }^{2}$ \\ ${ }^{1}$ Institute of Dermatology and Venereology, Clinical Center of Serbia, Belgrade, Serbia \\ ${ }^{2}$ Clinic of Dermatovenereology Diseases, Clinical Center of Vojvodina, Novi Sad, Serbia \\ *Correspondence: Bosiljka LALEVIĆ-VASIĆ, E-mail: labuba@eunet.rs
}

UDC 616.5:614.2(091)(497.11)"1919/1945"

UDC 616.97:614.2(091)(497.11)"1919/1945"

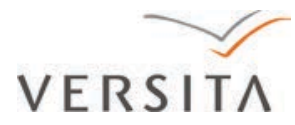

\begin{abstract}
After the First World War, Serbia was ravaged and in ruins, whereas the Health Care Service was destroyed. Organization and reorganization of the Health Care Service started with a fight against the spread of infectious diseases. Foundation of specialized health institutions was among the first tasks. As early as 1920, an Outpatient Service for Skin and Venereal Diseases was established and managed by Prof. Đorđe Đorđević. In 1922, after he was appointed as Associate Professor at the newly established Faculty of Medicine in Belgrade, he founded a Clinic for Skin and Venereal Diseases, and acted as its first director. In 1928, a Municipal Outpatient Clinic for Skin and Venereal Diseases was founded, whereas in 1938 a modern organization of the Service was established in a new building. After a break during the I World War, the Dermatovenereology Department of the General Military Hospital in Belgrade, founded in 1909, continued working until the Second World War. In Novi Sad, the City Hospital was founded in 1909, including a Dermatovenereology Department. After the First World War, in 1921, Dr. Jovan Nenadović founded a Department of Skin and Venereal Diseases (100 beds) in the General Public Hospital, as well as, an independent Public Outpatient Clinic for free-of-charge treatment of patients with venereal diseases. In Niš, the first Organization Unit for Venereal Diseases was founded in 1912, but the Department of Venereal Diseases was founded in 1921, and it was managed by Dr. Petar Davidović, while in 1927 a Department of Skin and Venereal Diseases was established within the General Public Hospital. In 1920, a Dermatovenereology Department of the Military Hospital in Niš was established. Apart from these, as early as 1921, there was a total of 7 Outpatient Clinics in Serbia, and in 1923 there were 14 venereal departments, and 1 dermatovenereology department.
\end{abstract}

\begin{abstract}
fter the First World War, the Kingdom of Serbs, ACroats and Slovenes was proclaimed in 1918, as well as the first Ministry of Public Health (MPH). Thus, the whole enlarged country was integrated into a unique system of health care delivery, although the initial positions of certain parts were quite different. The seven-year war $(1912$ - 1918), occupation and epidemics of infectious diseases led to a massive loss of lives and medical personnel in Serbia (1). Out of nearly three million inhabitants of Serbia before the First World War, over 1.200.000 people lost their lives (2), including $35 \%$ of physicians (1). The country was ravaged and in ruins $(1,3)$, whereas the Health Care Service was destroyed. Infectious and venereal diseases spread, and it was necessary to start organization and reorganization of the sanitary service (1). Again,
\end{abstract}

it meant starting from scratch, in somewhat better circumstances than earlier, because some habits and laws have been preserved, and the health care service had had a certain tradition.

\section{Legislation and Organization of the Dermatovenereology Service}

Shortly after the war, proper legal regulations were brought, but they were replaced in 1921 by the Law on the Foundation of Special Institutions for Infectious Diseases and Free-of Charge Health Care Service (1, 2). Based on this Law, the MPH was responsible for the: detection, eradication and treatment of acute and chronic infectious diseases, keeping strict records of patients and for health education of the population (1). The Law on the Eradication of Infectious Diseases, 
passed in 1930, included the following guidelines for venereology: foundation of institutions for freeof-charge treatment; employment of professionally educated physicians; foundation of hospital departments for venereal diseases; units for prevention of venereal diseases; institutions for the treatment of children with congenital syphilis; mobile outpatient services; forced treatment, and taking special measures in counties where more than $5 \%$ of population were infected by syphilis. Reporting diseases was mandatory in cases where spread of infection was anticipated. In 1931 and 1934, Laws on Eradication of Endemic Syphilis (1) and of Venereal Diseases were passed, respectively (4). Skin diseases were covered by General Legislation.

Three basic problems were recognized in the organization of public health care: insufficient number of hospitals and physicians, and almost complete lack of bacteriological laboratories (1). The first two problems were directly related to dermatovenereology.

\section{Health Institutions}

The Outpatient Service for Skin and Venereal Diseases (OSSVDs) was founded by a special regulation of the $\mathrm{MPH}$ in Belgrade in 1920, since it was the Center for organization of Sanitary Services in Serbia (1). Firstly it was situated in Dečanska Street, then in Vidinska Street (today George Washington street), which remained recognized as a location of the first dermatovenereology institutions in Belgrade, but also by a great number of brothels, which were there before and after the First World War (5). Dr. Đorđe Đorđević (Figure 1) was the Head of the OSSVDs, and Dr. Sima Ilić (Figure 2), was the dermatovenereologistpractitioner (6). Both of them were very important for the development of the Serbian dermatovenereology. The Service provided a temporary residence to the newly founded Clinic for Skin and Venereal Diseases (see below). When the Clinic was moved in 1925, the OSSVDs continued working as the institution of the $\mathrm{MPH}$, and Dr. Sima Ilić was the Head of the Service (6).

The Clinic for Skin and Venereal Diseases (CSVDs) was founded in 1922, when dr Đorđević was appointed as Associate Professor at the newly established Faculty of Medicine in Belgrade (1920) (7). The Clinic had no capacities for in-patients (8), but all other health and

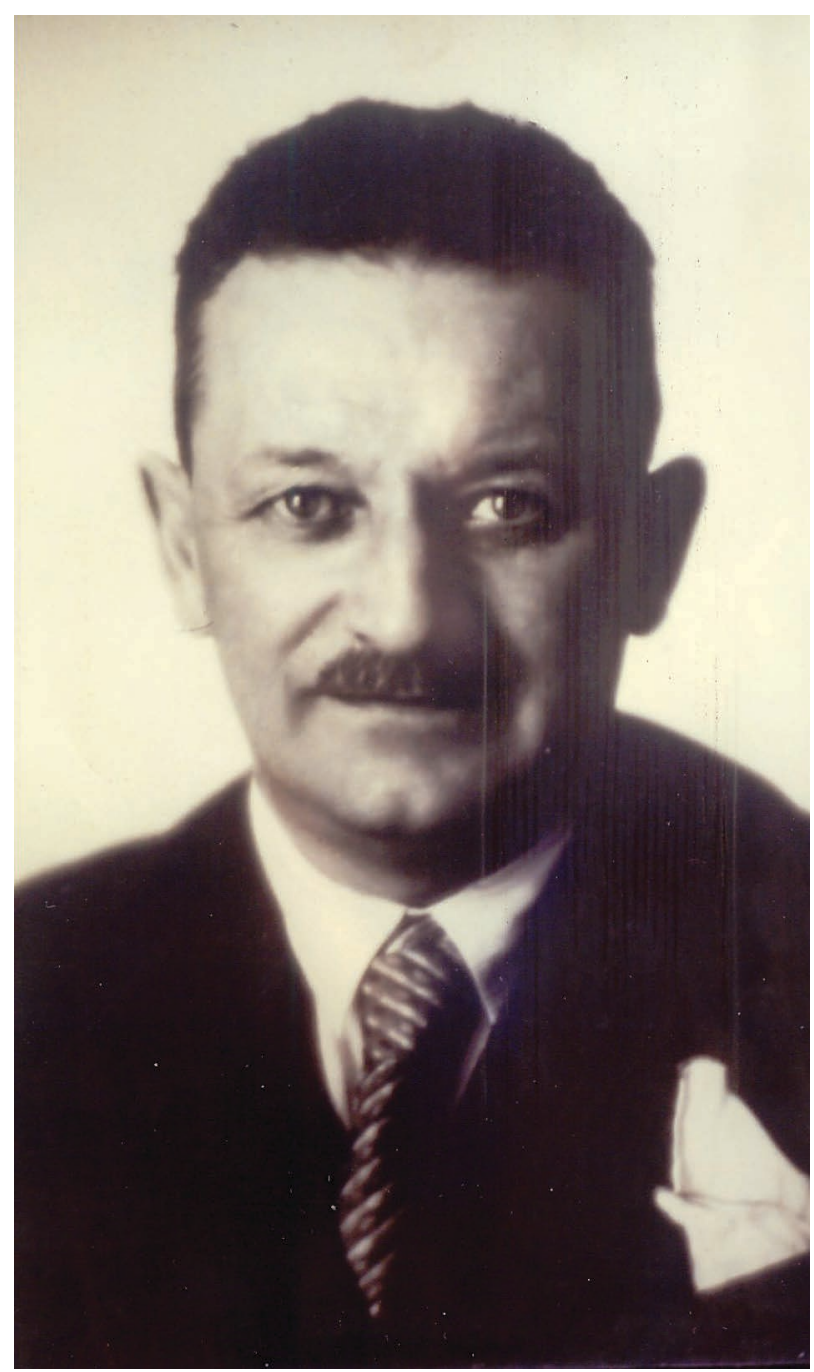

Figure 1. Prof. Dr. Đorđe Đorđević

educational activities were exercised at the OSSVDs, based on the agreement between the Faculty of Medicine and the MPH (6). Till 1932, the CSVDs has been moved two more times into private residences, unfortunately always in inadequate premises. Hospital departments were founded in 1925, whereas in 1932, the CSVDs was moved to the facilities of the Institute of Anatomy, which had previously been used by the (cancelled) Clinic of Applied Anatomy (6) (Figure 3). The working conditions were somewhat better, and apart from hospital departments and laboratories, in 1935 the Clinic possessed a library with 700 books and 450 journals, as well as a moulage collection of 400 exhibits (7). Apart from this, in 1935 a Specialized Outpatient Service was opened for treatment of 


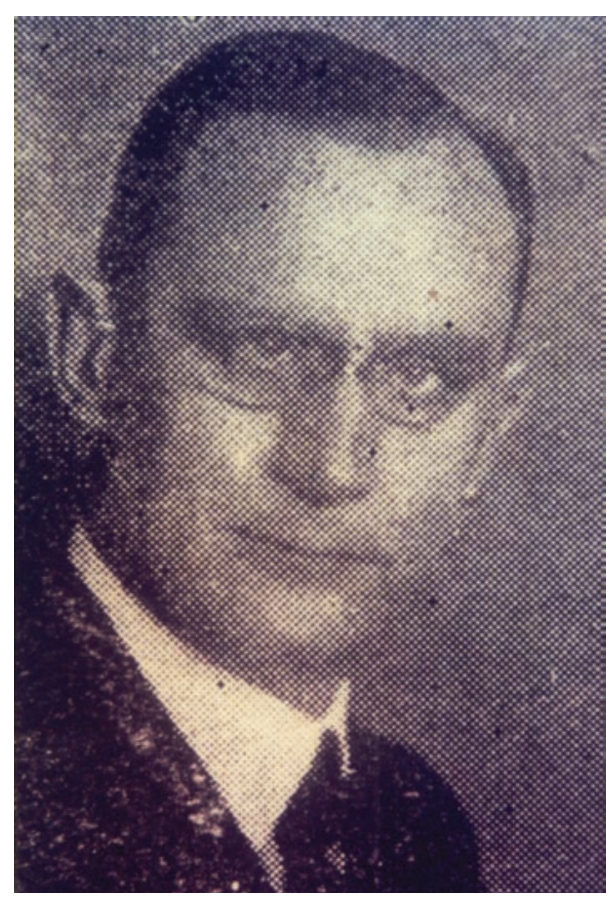

Figure 2. Prof. Dr. Sima Ilić

students (9). During the Second World War, the occupation authorities took possession of the Clinic with the entire inventory, so that only the Outpatient Service continued working. After the Germans had left in 1944, part of the library and the moulage collection remained behind (10). The first Head of the
CSVDs was Professor Đorđe Đorđević (1922 - 1935), followed by Professor M. Kićevac $(1935$ - 1940) (7), and Dr. Sava Bugarski (1940 - 1944) $(6,11)$.

The Dermatovenereology Departments of the General Public Hospital (GPH), founded in Belgrade at the end of the XIX century (see part III/1), the first dermatovenereology departments for in-patients in Serbia, continued working after the First World War.

The Municipal Outpatient Clinic for Skin and Venereal Diseases in Belgrade was founded on September 15, 1928. During the following ten-year period, it was housed in inadequate private facilities, with small and disorganized settings (Figure 4). When the economic crisis ended in the 1930s, a new building was built in 1938 in Vidinska Street (17, George Washington Street), and it was called the City Outpatient Clinic, today City Department of Skin and Venereal Diseases. It was a modern building and it was the first institution of its kind in Central Europe (Figure 5). The Head of the Institution was Dr. Jovan Spasojević who worked with Dr. Mihailo Gačić, both dermatovenereologists. Its significance can easily be seen from the following data: during 1928, a total of 1.072 patients were examined, in 1929, 15.217 patients, and in 1937, 51.194 patients had undergone examination (5).

The Department of Skin and Venereal Diseases $(100$ beds) of the General Public Hospital (GPH) (Figure 6),

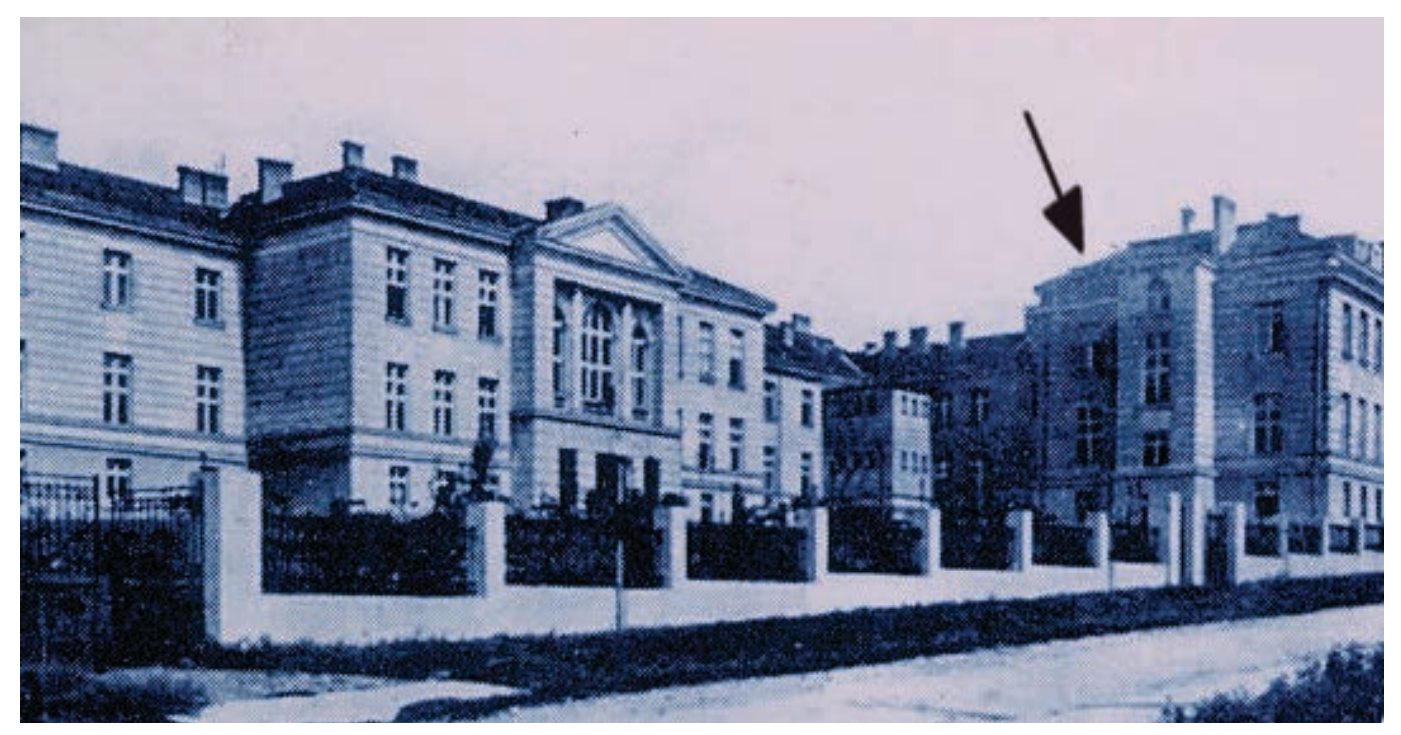

Figure 3. The Institute of Anatomy in Belgrade, a temporary residence of the Clinic for Skin and Venereal Diseases in 1932 (indicated by an arrow) 


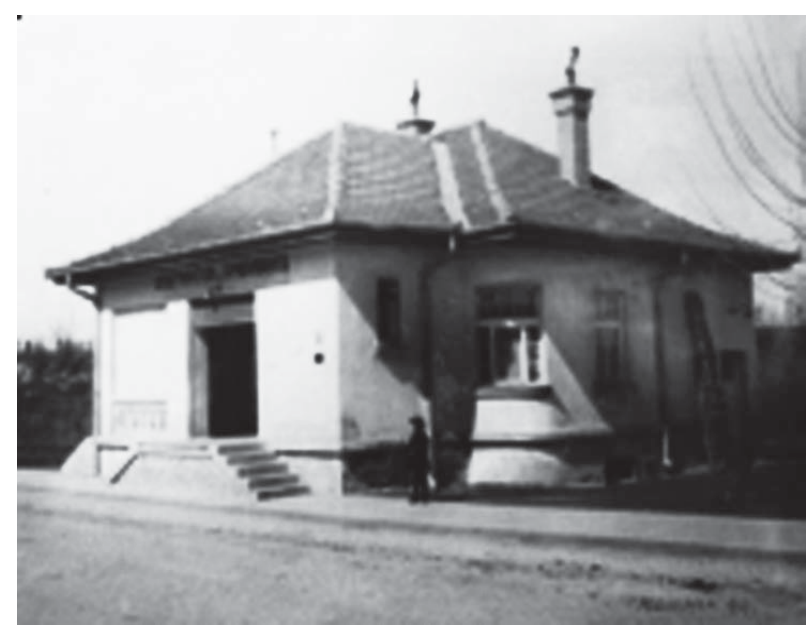

Figure 4. The Municipal Outpatient Clinic for Skin and Venereal Diseases in Belgrade

and the independent Public Outpatient Clinic for freeof-charge treatment of patients with venereal diseases in Novi Sad, were founded in 1921, by Dr. Jovan Nenadović, the first Serbian dermatovenereologist in Vojvodina. He was the director of both institutions (12). We must also note that in 1909, the City Hospital with a Dermatovenereology Department was founded (13), but after the First World War there was no place for treatment of patients with skin and venereal diseases (12). Apart from that, an AntiVenereal Outpatient Department was founded in 1925 (13). Further development of dermatovenereology in Vojvodina started with these institutions with close cooperation with the Belgrade Dermatology School. Dermatovenereologists, who took part in the development of dermatovenereology, and in the work of institutions of that time, were also members of the Dermatovenereology Section of the Serbian Medical Association.

The first Organization Unit for Venereal Diseases in Niš was founded in 1912, and in 1920 it was moved into the bungalows of the City Hospital. The Department for Venereal Diseases with an Outpatient facility outside the Hospital circle was founded in 1921 and it was managed by Dr. Petar Davidović. A Department for Skin and Venereal Diseases of the GPH in Niš was opened in 1927. Its director was Dr. Petar Zurin, a dermatovenereologist $(1,14)$. After the foundation of the Faculty of Medicine in Niš (1960) it had become a teaching hospital for medical students (14) (Figure 7).

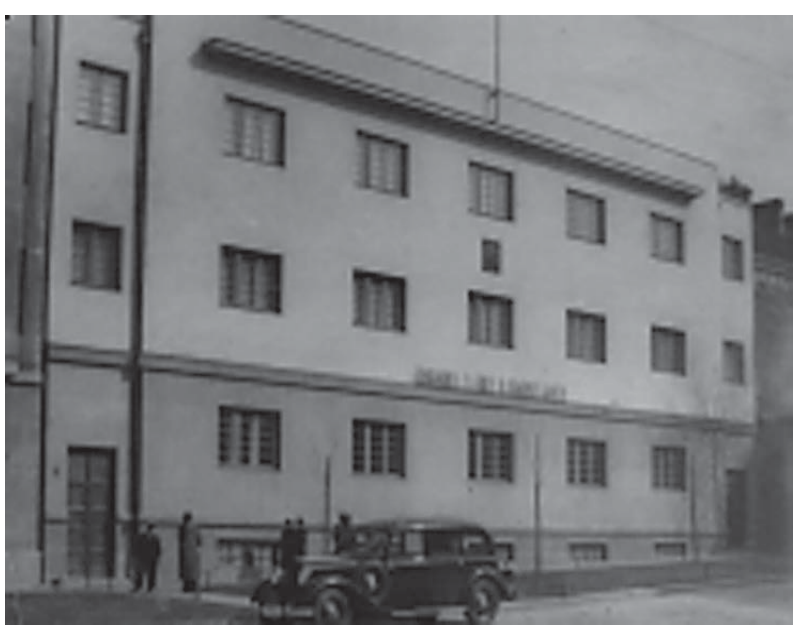

Figure 5. The City Outpatient Clinic for Skin and Venereal Diseases in Belgrade

In 1921, at the initiative of Prof. Đ. Đorđević, Serbia had complete outpatient health care centers in Niš, Petrovac, Užice, Boljevac County, Subotica, Veliki Bečkerek (Zrenjanin) and Mitrovica (15). As soon as 1923, general hospitals had 14 venereal departments and 1 dermatovenereology department,

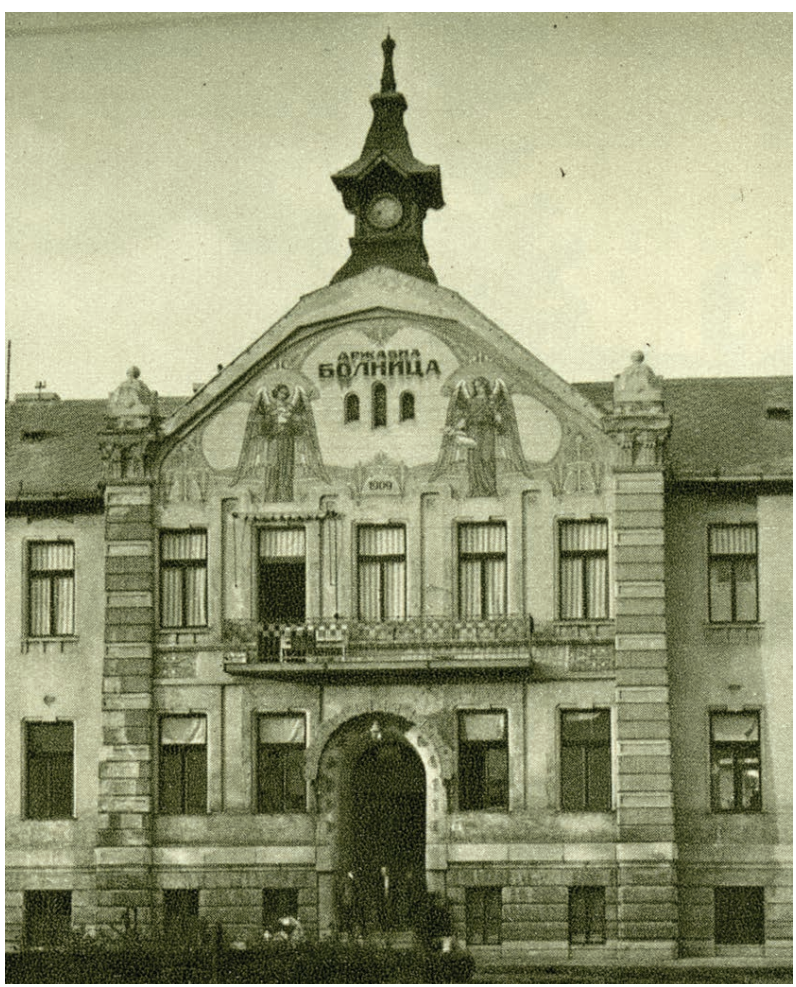

Figure 6. The General Public Hospital in Novi Sad with the Department of Skin and Venereal Diseases (Archive of Vojvodina) 


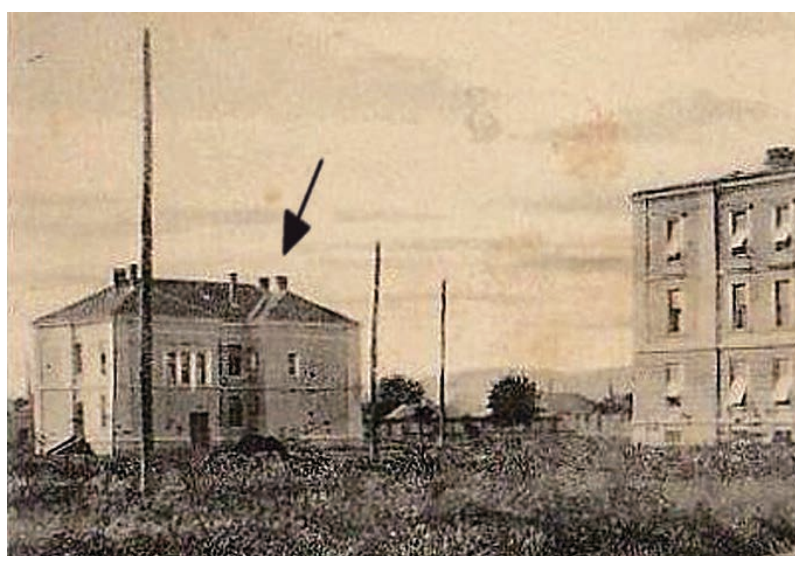

Figure 7. The General Public Hospital in Niš, the present Clinic for Skin and Venereal Diseases (indicated by an arrow)

in Subotica (16). It is noticeable that these departments were called "venereal", just as the physicians were called "venereologists" (1), pointing once again to the fact that venereal diseases were still a major dermatovenereology problem.

The Dermatovenereology Department of the General Military Hospital in Belgrade, founded in 1909 (see part III/1), worked until the First World War, when the General Military Hospital, under the Austrian occupation, became "Das K. und KReservspital Brško" (17). After the war, the Department continued working till the beginning of the Second World War.

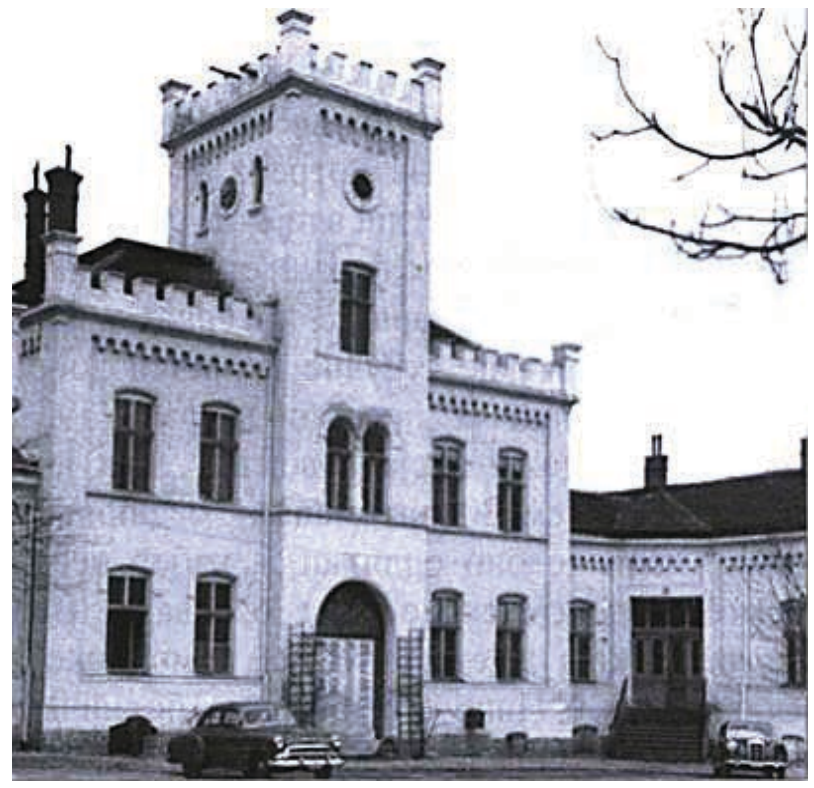

Figure 8. The Main Military Hospital in Belgrade with the Dermatovenereology Department

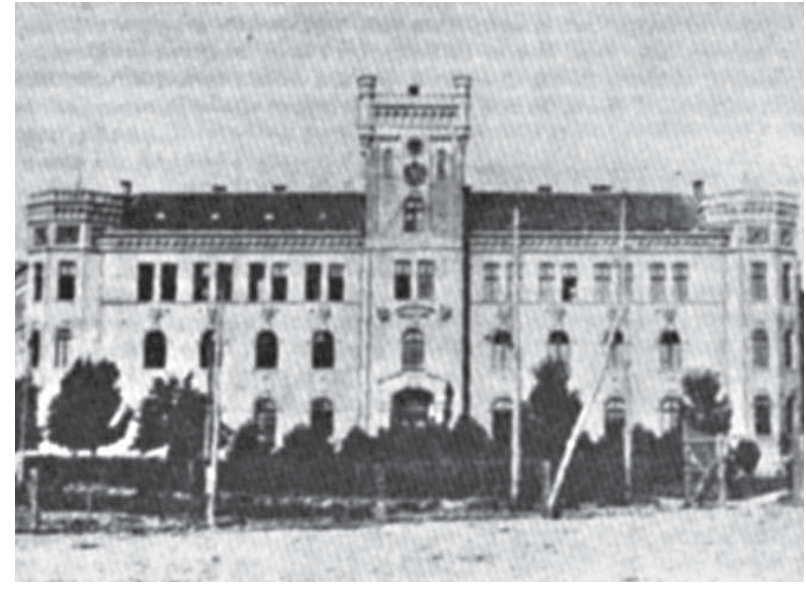

Figure 9. The Military Hospital in Niš with the Dermatovenereology Department

From 1941 to 1944, the occupation authorities once again used the General Military Hospital for their purposes (18). After the war, it continued working as the Main Military Hospital, moreover, the, Dermatovenereology Department continued working as well (19) (Figure 8).

After the First World War, in 1920, new departments were founded in the Military Hospital in Niš (Army Military Hospital for the territory of Moravska military district) (Figure 9), including a Dermatovenereology Department (20).

The first hospital for the treatment of syphilis in Serbia was founded in 1851 in Knjaževac (see part II), but during time it was transformed into the County General Hospital (21). With the archive destroyed, there is no evidence of its work, but it is apparent that patients with syphilis prevailed, because it is well known that at the beginning of the 1950's, this was the most outspread and best known area with endemic syphilis in Serbia (22).

\section{References}

1.Milovanović V. editor. Medicinski godišnjak Kraljevine Jugoslavije (Annual Medical Report of the Kingdom of Yugoslavia). Beograd Jugoreklam K.D; 1933.

2.Djokić D, Dovijanić P. Osamdeset godina u službi zdravlja naroda. 2. izd. (80 $0^{\text {th }}$ Anniversary of the Public Health Service, $2^{\text {nd }}$ ed). Beograd: Institut za zaštitu zdravlja Srbije "Dr Milan Jovanović Batut", Medicinski fakultet u Beogradu, Univerzitet u Beogradu; 2000.

3. Davidović U. Dvadeset godina Opštine beogradske $\left(20^{\text {th }}\right.$ Anniversary of Belgrade Municipality). Beogr Opšt Nov 1939;57(1-2):7-14.

4. Zorko T. Ženska prostitucija u Zagrebu 1899. i 1934.godine 
(Female prostitution in Zagreb in 1899 and 1934). Časopis Suvrem Pov 2006;38(1):223-41.

5. Kićevac M. Gradska poliklinika za kožne i venerične bolesti (City Outpatient Clinic for Skin and Venereal Diseases). Beogr Opšt Nov 1938;56(3):215-7.

6. Kićevac M. Klinika za kožne i venerične bolesti (Clinic for skin and Venereal Diseases). U: Medicinski fakultet Univerziteta u Beogradu 1920-1935. Beograd: Medicinski fakultet; 1935. p. 125-31.

7. Stefanović S. et al. editors. 50 godina Medicinskog fakulteta Univerziteta u Beogradu 1920-1970. (50 ${ }^{\text {th }}$ Anniversary of the School of Medicine of the Belgrade University - 1920 - 1970). Beograd: Galenika; 1970.

8. Pregled predavanja za zimski semestar 1924/1925 godine; Univerzitetski kalendar (The Winter Curriculum for the academic years 1924/1925; University Calendar). Beograd: Univerzitet u Beogradu; 1924/1925.

9. Univerzitet u Beogradu 44 (Belgrade University 44). Beograd: Publikacija Rektorata; 1935/1936.

10. Izveštaj Medicinskog fakulteta, nezaveden i nedatiran akt, Arhiv Srbije (Report of the School of Medicine, unrecorded and undated publication, Archive of Serbia).

11. Pregled predavanja za zimski semestar 1940/1941.godine (The Winter Curriculum for the academic years 1940/1941). Beograd: Univerzitet u Beogradu; 1940/1941.

12. Pedesetogodišnjica lekarskog i kulturnog rada dr Jovana Nenadovića ( $50^{\text {th }}$ Anniversary of the health and cultural work of Dr. Jovan Nenadović). Med Pregl 1951;(9-10):1-3.

13. NN. Razvoj medicine u Novom Sadu (Progress of medicine in Novi Sad). U: Budakov P, Pejin D, editors. Univerzitet u Novom Sadu, Medicinski fakultet Novi Sad, 1960-2000: Medicinski fakultet; 2000. p. 8-15.

14. Krstić S. 80 godina službe i 20 godina Klinike za kožne i polne bolesti u Nišu (80th Anniversary of the Service and 20th Anniversary of the Clinic for Skin and Venereal Diseases in Niš). Niš: Univerzitetski klinički centar OJ Klinike za kožne i polne bolesti; 1991 .

15. Djordjević Dj. Izveštaj o radu Ambulante za kožne i venerične bolesti u Beogradu; Prilog "Glasniku Ministarstva Narodnog Zdravlja” (Work report of the Outpatient Clinic for Skin and Venereal Diseases in Belgrade; Addition to the "Journal of the Ministry of Public Health"). Beograd; 1921:1-35.

16. Popović DG. O bolnicama (About Hospitals). Glasnik Ministarstva Narodnog Zdravlja. Vanredno izdanje. Beograd; 1923:3-162.
17. Stojiljković MP, Zeljković J, Tadić V. Iz istorije Vojnomedicinske akademije: I Vojne bolnice u Beogradu od 1836. do 1938. godine (Out of the history of the Military Medical Academy: I Military Hospitals in Belgrade from 1836 to 1938). Vojnosanit Pregl 2002;59 (3):329-33.

18. Špirić Ž, Preradović M, Zeljković J. Iz istorije srpske i jugoslovenske vojne psihijatrije: Nastanak i razvoj Klinike za psihijatriju Vojnomedicinske akademije od 1932. do 2002. godine. (Out of the history of Serbian and Yugoslav military psychiatry: Foundation and progress of the Clinic of Psychiatry of the Military Medical Academy from 1932 to 2002). Vojnosanit Pregl 2002;59(6):681-7.

19. Dinić MŽ, Kandolf-Sekulović L, Zečević RD. Sto godina dermatovenerologije u Vojsci Srbije (A hundred years of dermatovenereology in the Serbian Army). Vojnosanit. Pregl. 2010; 67(1): 73-6

20. Vojna bolnica Niš (Military Hospital in Niš). Wikipedia (cited in December, 2009). Available from: http: // sr.wikipedia. org/sr-el.

21. Ivanović Šakabenta D. Sto pedeset godina bolnice u Knjaževcu 1851-2001. (150 th Anniversary of the Hospital in Knjaževac: 1851 - 2001). Knjaževac: Zdravstveni centar Knjaževac; 2001.

22. Ilić S, Ignjatović B. Endemski sifilis u Srbiji; Savremena akcija na njegovom suzbijanju

(Endemic Syphilis in Serbia; An Eradication Campaign). Beograd: Biblioteka Higijenskog instituta NR Srbije; 1957.

\section{Abbreviations}

CSVDs - Clinic for Skin and Venereal Diseases

GPH - General Public Hospital

MPH - Ministry of Public Health

OSSVDs - Outpatient Service for Skin and Venereal Diseases

\section{Acknowledgement}

With great pleasure, we acknowledge our gratitude to Dr. Simon Dragović and Prof. Dr. Snežana Veljković. We also wish to acknowledge our gratitude to Prof. Dr. Branislav Filipović, Prim. Dr. Aleksandar Adamović and Assistant Prof. Dr. Lidija Kandolf-Sekulović, for their assistance in gathering valuable photographs. 